\title{
Effects of Demersal Otter Trawls on the Re-suspension of Copepod Resting Eggs and its Potential Effects on Recruitment
}

\author{
Hansen, Benni Winding; Drillet, Guillaume; Hay, G; O'Neill, F.G.
}

Published in:

Journal of Fisheries and Livestock Production

DOI:

$10.4172 / 2332-2608.1000114$

Publication date:

2014

\section{Document Version}

Publisher's PDF, also known as Version of record

Citation for published version (APA):

Hansen, B. W., Drillet, G., Hay, G., \& O'Neill, F. G. (2014). Effects of Demersal Otter Trawls on the Resuspension of Copepod Resting Eggs and its Potential Effects on Recruitment. Journal of Fisheries and Livestock Production, 2(1). https://doi.org/10.4172/2332-2608.1000114

\section{General rights}

Copyright and moral rights for the publications made accessible in the public portal are retained by the authors and/or other copyright owners and it is a condition of accessing publications that users recognise and abide by the legal requirements associated with these rights.

- Users may download and print one copy of any publication from the public portal for the purpose of private study or research.

- You may not further distribute the material or use it for any profit-making activity or commercial gain.

- You may freely distribute the URL identifying the publication in the public portal.

\section{Take down policy}

If you believe that this document breaches copyright please contact rucforsk@kb.dk providing details, and we will remove access to the work immediately and investigate your claim. 


\section{Effects of Demersal Otter Trawls on the Re-suspension of Copepod Resting Eggs and its Potential Effects on Recruitment}

\author{
Drillet $\mathbf{G}^{1^{*}}$, Hay $\mathrm{S}^{2}$, Hansen BW ${ }^{1}$ and O'Neill FG ${ }^{2}$ \\ ${ }^{1}$ Department of Environmental, Social and Spatial Changes, Roskilde University, Denmark \\ ${ }^{2}$ Marine Scotland Science, 375 Victoria Road, Aberdeen, AB11 9DB, Scotland
}

"Corresponding author: Guillaume Drillet, DHI-NTU Research Centre and Education Hub, 1 Cleantech Loop, \#03-05 CleanTech One, Singapore 637141, Tel: +65 6777 6330; E-mail: gdr@dhigroup.com

Rec date: Apr 26, 2014, Acc date: May 28, 2014, Pub date: Jun 15, 2014

Copyright: () 2014 Drillet G, et al. This is an open-access article distributed under the terms of the Creative Commons Attribution License, which permits unrestricted use, distribution, and reproduction in any medium, provided the original author and source are credited.

\begin{abstract}
Resting eggs are important phases in the life strategy of many coastal and estuarine copepods. The egg mortality in the sediment layers where they are buried, as well as re-suspension from the sediment into the water column where eggs may hatch are factors that affect the success of this life strategy. Considering that fishing effort in some coastal areas is high and trawling leads to re-suspension of the bottom sediments, it is important to understand these effects on the biology of organisms that utilize sediment habitats in part of their life cycle.

This study examined the re-suspension and the hatching success of copepod resting eggs in the wake of two different demersal fishing gear components (doors and discs) that are in contact with the seabed, in two areas off the coast of Scotland that are rarely worked by fishermen. Sediment cores were taken and analysed for resting eggs quantity and hatching performance and compared with samples taken in the water column right after re-suspension of sediment by the gear components. This study demonstrated for the first time that although eggs are re-suspended in the water column together with the sediment, providing them with the opportunity to hatch and recruit nauplii to the pelagic, egg viability was reduced by the passage of the gear components. This study also suggests that the viability is dependent on the gear component and accordingly potential effects must be considered for at this level.
\end{abstract}

Keywords: Copepod resting eggs; Sediment cores; Hydrodynamic; Benthic habitat

\section{Introduction}

Resting eggs are produced by around 50 species of calanoid copepods $[1,2]$ and are known to be produced to survive harsh environmental conditions [3]. The roles of these eggs in the life cycle of many ecologically important species are often underestimated despite a seasonal occurrence of species disappearance from the water column $[4,5]$. Different types of resting eggs have been described in the literature and represent different types of survival strategies. There are: immediate survival strategies (quiescent eggs), short-term resting strategies (e.g. delayed hatching eggs), and long-term survival strategies (diapause) where eggs accumulate in the sediment as an egg bank, saving these genes for the future [6-10]. It is, however, difficult to separate eggs according to these categories when sampled from the sea bed because diapause and delayed hatching eggs for which hatching is maternally controlled may lie in the sediment under quiescence once their refractory period is over. Also, morphological approaches for the identification of eggs often produce contradictory results and therefore must be used cautiously [11-13].

Eggs in the sediment may be subject to predation, infection and senescence, [14]. However, these eggs may also be released from their resting stage after re-suspension in the water column following the mobilization of sediment as a result of anthropogenic, physical and biological disturbances [15].

Demersal trawl fishing is one of the most widespread anthropogenic activities that affect the seabed. Towed demersal fishing gears can significantly impact the benthic ecosystem and many previous studies have shown that such gears can damage benthic organisms, alter the benthic habitat and sediment structure $[16,17]$. The physical interaction of towed demersal gears and the sea bed can be broadly classified as being either geotechnical or hydrodynamic in nature [18]. The penetration, piercing and lateral displacement of the sediment can be considered to be geotechnical [19] and the associated pressure and shearing forces may damage benthic in fauna and habitat. The turbulent shearing in the wake of the gear components are hydrodynamic and these give rise to the mobilization of sediment into the water column (e.g. $[20,21])$. The mobilization of sediment has been related to the re-suspension of phytoplankton cysts and zooplankton resting eggs [22-24], however, the extent to which the passage of a fishing gear affects the viability of these stages has never been assessed. The present study is aimed to obtain an initial understanding of these processes, and to explore how demersal trawl fisheries may affect the re-suspension and viability of copepod resting eggs.

\section{Material and Methods}

\section{Sample collection}

Experimental trials were carried out during November 2007 by the RV Clupea close to Nairn $\left(57^{\circ} 37^{\prime} \mathrm{N} 3^{\circ} 54^{\prime} \mathrm{W}\right.$ at depths $\sim 22 \mathrm{~m}$ ) and close to Burghead $\left(57^{\circ} 41^{\prime} \mathrm{N} 3^{\circ} 45^{\prime} \mathrm{W}\right.$ at depths $\left.\sim 54 \mathrm{~m}\right)$, two areas within the Moray Firth on the northeast coast of Scotland. To quantify the sediment type and the depth distribution of eggs, 6 core samples ( $\varnothing 10$ $\mathrm{cm}$ ) were taken at each site using a Sholkovitz corer and sectioned in three different depth intervals: $0-2 \mathrm{~cm}, 2-6 \mathrm{~cm}$ and $6-14 \mathrm{~cm}$ on board the ship. 
Page 2 of 5

For the assessment of the fishing gear effects on the sea bed and the resting eggs buried into it, two different components of a demersal trawl were used: a trawl door, which is used to spread the mouth of the trawl net and ensure it maintains contact with the seabed (rectangular $1.37 \mathrm{~m} / 0.88 \mathrm{~m}, 101 \mathrm{~kg}$ ) ; and a rubber disc section of the ground gear, which is used to protect the fishing net and maintain contact with the seabed (Ø $15 \mathrm{~cm} / 3.5 \mathrm{~cm}$ thick, $1.36 \mathrm{~m}$ long, $20.6 \mathrm{~kg}$ ) [24]. The gear components were towed individually from the vessel at a speed of $\sim 1$ $\mathrm{ms}^{-1}$ (2 knots) during $15 \mathrm{~min}$ tows and a benthic sledge was attached behind the components to sample the sediment plume at 35, 55 and 80 $\mathrm{cm}$ above sea bed (for the trawl doors) or $35 \mathrm{~cm}$ above seabed (for the rubber discs) by using a $20 \mu \mathrm{m}$ mesh size plankton net with a $\varnothing 6.0 \mathrm{~cm}$ opening [24]. Two trawls (3 mesh samples for each) were carried out at each station to evaluate the effects of doors and six trawls (1 mesh sample for each) were carried out at each station after the rubber discs.

All samples (plankton net and core) were kept at $5^{\circ} \mathrm{C}$ on the research vessel and transferred to the laboratory after the cruise.

\section{Analysis of cores and net samples}

Sediment samples from the cores and the plankton net were processed in the laboratory the week following the cruise. Cores from each sampling sites were processed as following: two samples were fixed in buffered formalin $4 \%$ final concentration for counting, three were used for hatching experiments and the last sediment sample was analysed using a Malvern Instruments Mastersizer E Particle Size Analyser.

The first set of mesh samples ( 3 samples) harvested after the doors and three sets of mesh samples harvested after the rubber discs were used for counting the number of eggs re-suspended in the water column (formalin 4\%). The second set of mesh samples (3 samples) harvested after the doors and three other sets of mesh samples harvested after the rubber discs were used for the hatching experiment. There was no particle size analysis done on the sediment harvested in the mesh after re-suspension.

Particles less than $20 \mu \mathrm{m}$ are partly lost through the meshes during trawling and therefore, comparing the egg density in the cores and the mesh samples was done by pondering the counted number of eggs in all samples with the weight of the 50-200 $\mu \mathrm{m}$ sediment fraction (successive filtrations of a known sample volume). For fixed samples, the $50-200 \mu \mathrm{m}$ fraction containing resting eggs was transferred into LUDOX solution $40 \%$, mixed and centrifuged at $900 \mathrm{~g}$ [25]. The upper fraction containing the eggs was rinsed on a $50 \mu \mathrm{m}$ mesh and eggs were enumerated under a dissection microscope at 40X magnitude.

The live samples (cores and plankton net) were rinsed through 200 and $50 \mu \mathrm{m}$ filters with $10 \mu \mathrm{m}$ filtered sea water (FSW) and the 50-200 $\mu \mathrm{m}$ fraction containing eggs was incubated in the dark at $12^{\circ} \mathrm{C}$ in 100 $\mathrm{ml}$ cell culture flasks in FSW on a rocking table to ensure gentle movement of water and sediment and thereby oxygen to the resting eggs in the flasks. Every three days, the water was exchanged; nauplii were harvested and fixed in formalin for later identification. The hatching experiment lasted for 35 days and at the end of the incubation, the remaining eggs were counted and the weight of the sediment fraction was obtained.

\section{Statistical analysis}

For statistical analysis, ANOVAs were carried out and followed with pairwise comparison tests (Holm-Sidak method with $\mathrm{p}=0.05$ ) using Sigma plot ( ${ }^{\circ}$ V.12.3).

\section{Results}

\section{Sediment structure and egg distribution}

The sediment was classified as a mixture of poorly sorted 'muddy sand' and 'sandy mud' at Nairn and poorly sorted 'sandy mud' at Burghead [26]. The percentage silt $(<63 \mu \mathrm{m})$ in the sediments was 54 and $66 \%$ by volume, respectively (Table 1 ).

\begin{tabular}{|c|c|c|c|c|c|}
\hline & $\begin{array}{l}\text { Mean } \\
\text { particle } \\
\text { size }(\mu \mathrm{m})\end{array}$ & $\begin{array}{l}\text { Median } \\
\text { particle size } \\
(\mu \mathrm{m})\end{array}$ & $\begin{array}{l}\% \text { below } \\
63 \mu \mathrm{m}\end{array}$ & $\begin{array}{l}\% \text { below } \\
20 \mu \mathrm{m}\end{array}$ & $\begin{array}{l}\text { Folk } \\
\text { description }\end{array}$ \\
\hline Nairn & $73.6 \pm 9.6$ & $58.9 \pm 7.8$ & $\begin{array}{ll}53.9 \quad \pm \\
6.0\end{array}$ & $\begin{array}{ll}17.2 & \pm \\
1.4 & \end{array}$ & $\begin{array}{l}\text { Sandy Mud and } \\
\text { Muddy sand }\end{array}$ \\
\hline Burghead & $56.0 \pm 2.4$ & $42.1 \pm 2.1$ & $\begin{array}{l}66.0 \quad \pm \\
1.9\end{array}$ & $\begin{array}{ll}26.4 & \pm \\
1.22 & \end{array}$ & Sandy Mud \\
\hline
\end{tabular}

Table 1: Sediment composition in the study areas. Mean \pm SD

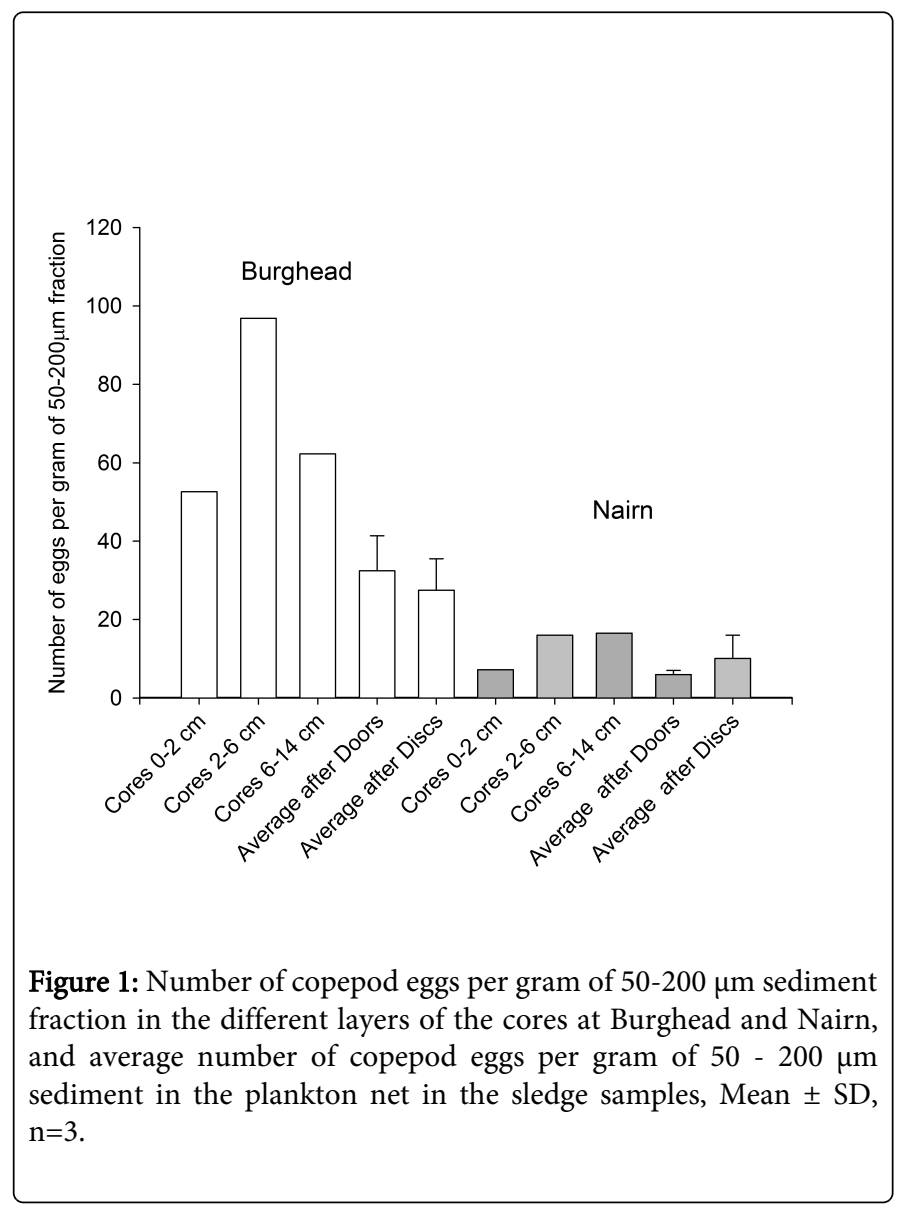

The eggs density across the three layers of sediment varied from 15.1 to 30.8 eggs $\mathrm{cm}^{-3}$ in the sediment of Burghead and from 6.5 to 13.9 eggs $\mathrm{cm}^{-3}$ at Nairn (mean of two cores). The density of eggs in the surface and bottom layers of Burghead was lower than in the middle 
Citation: Drillet G, Hay S, Hansen BW and O'Neill FG (2014) Effects of Demersal Otter Trawls on the Re-suspension of Copepod Resting Eggs

fraction $(2-6 \mathrm{~cm})$. Comparatively the Nairn samples had a lower density of eggs at the surface and similar densities in the two deeper sediment layers. The number of eggs per gram of the $50-200 \mu \mathrm{m}$ sediment fractions in the three sediment layers follows the same distribution pattern (Figure 1). The density of eggs $\mathrm{m}^{-2}$ of surface area can be estimated by integrating the egg density in all three layers of sediment and gives $3.08 \times 10^{6}$ eggs m$^{-2}$ and $1.71 \times 10^{6} \mathrm{eggs} \mathrm{m}^{-2}$ in the Burghead and Nairn sediments, respectively.

\section{Egg re-suspension and incubation}

Fewer eggs tend to accumulate per gram of the 50-200 $\mu$ m sediment fraction in the plankton net samples of Burghead than in the cores at the same location but no trends are observed at Nairn (Figure 1).

Eggs in the incubation experiment start hatching after 3 days and most of the eggs hatched within the first ten days of incubation independently from their origin. Only eggs from Nairn $(6-14 \mathrm{~cm})$ and Burghead (after Discs) presented a less clear and more delayed pattern (Figure 2).

Most eggs hatching were from the Centropages spp. and Temora spp. genera, only a few Acartia spp. nauplii emerged from the 35 days incubation period at Nairn. The occasional occurrence of harpacticoid copepods was ignored from the study (Figure 3).

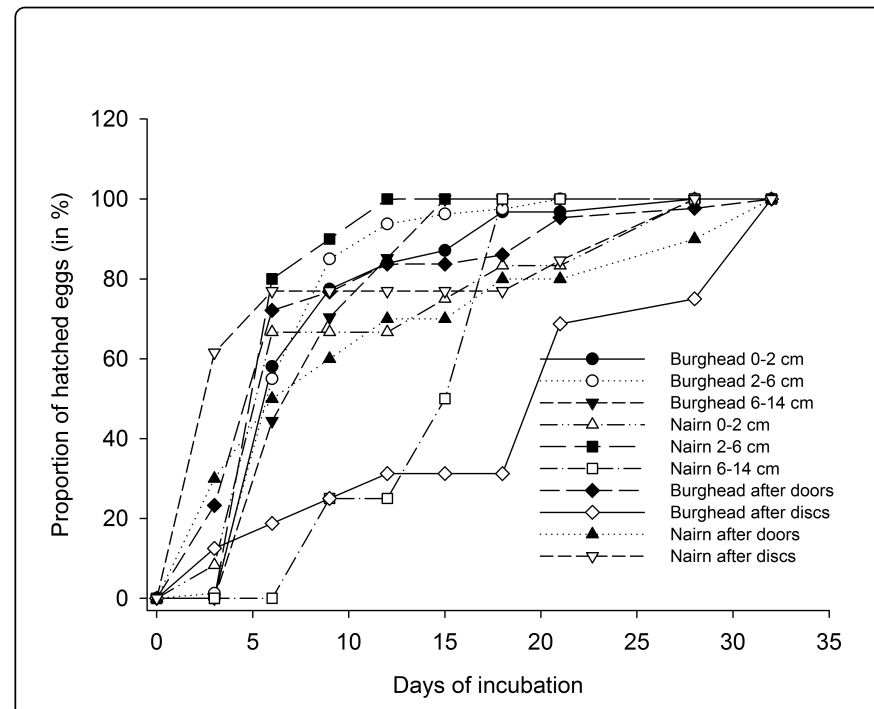

Figure 2: Accumulated calanoid copepod egg hatching rate over time during the incubations

The hatching rates of eggs in the cores ranged from $2.1 \%$ to $8.7 \%$ of the incubated eggs (Figure 4). Interestingly, the hatching success of these eggs, which were harvested directly from the sediment, was higher than those sampled from the water column after the passage of the gear components (ANOVA with a Holm-Sidak post hoc test, $\mathrm{p}<0.05)$. Furthermore, the hatching success of those eggs taken in the wake of the rubber discs tended to be higher than those taken in the wake of the heavier door.

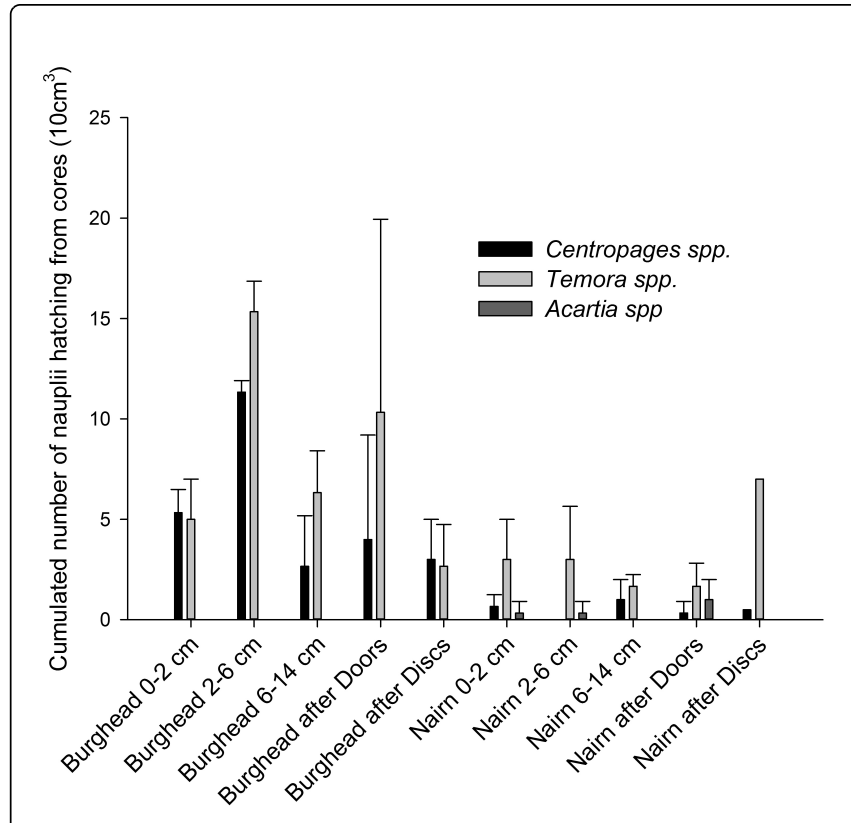

Figure 3: Calanoid copepod nauplii hatching from $10 \mathrm{~cm}^{3}$ of sediment at Burghead and Nairn in the different sediment layers. Mean $\pm S D, n=3$.

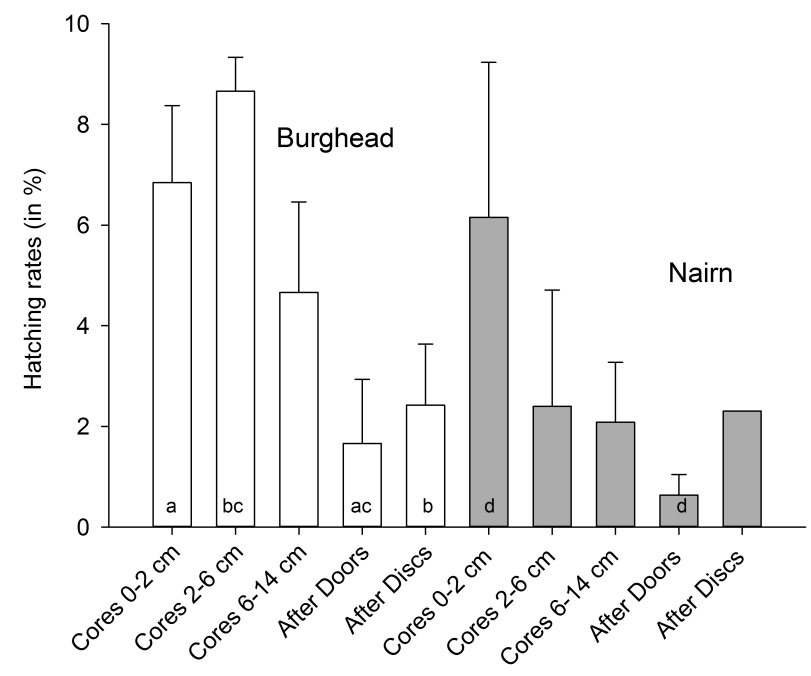

Figure 4: Hatching success of copepod eggs in the different layers of sediment from Burghead and Nairn and hatching success of eggs harvested in the water column just after the utilization of doors and discs. Mean $\pm S D, n=3$. Bars marked with a similar letter are statistically different (ANOVA $\mathrm{p}<0.05)$. 
Page 4 of 5

\section{Discussion}

Eggs from calanoid copepods were present at both stations, in the different sediment layers, within the range of egg densities previously reported in other sediments around the world $[27,28]$.

There were more eggs found present in all layers of the finer Burghead sediment than in the coarser Nairn sediment, supporting what has been reported elsewhere [23,24]. These observations are likely to reflect differences of the local hydrodynamic processes whereby both the finer sediments and the comparatively lighter eggs (with a relative density of about $1.05-1.2$ as opposed to approximately 2.65 for quartz based sediments) will have a greater tendency to settle and remain in less dynamic areas. Furthermore, the upper sediment layers $(0-2 \mathrm{~cm})$ at both Burghead and Nairn contained the fewest number of eggs, while the most were found in the $2-6 \mathrm{~cm}$ layer which is possibly due to the eggs in the top layers being more available for resuspension and subsequent hatching [29].

Interestingly, there were fewer eggs in the suspended sediments of Burghead than in the cores at the same site but this trend was not obvious at Nairn. This probably reflects that it is only the top layer of sediment (where there are fewer eggs) that is re-mobilized and that it is the finer fraction of this layer that is more likely to be re-suspended and sampled in the plankton nets.

The hatching rates values found in the present study are slightly lower than those described by Marcus [30] where up to $21 \%$ of the eggs hatched and far from what is reported in other sediments from the Baltic Sea $(\sim 80 \%$ [31]). There were close to no hatching from Acartia spp. in the present experiment. This could be due to that eggs may have not received the cues for hatching in the present experiment (such as light; [32] but which could also be dependent on temperature, salinity etc.). Considering that Acartia spp. are found in the pelagic in the area [33] during the summer and spring and its disappearance from the water column is likely to be linked with the production of resting eggs [34], it is very likely that eggs are present in the sediment but have not been source of hatching in the present study. Hypothetically, Centropages spp. and Temrora spp were not affected by the lack of light during the present incubations.

Nevertheless, even if all cues that may have allowed a higher hatching success were not tested during the present study, the hatching success was higher for eggs harvested directly from the sediment than those sampled from the sediment plume in the wake of the gear components, demonstrating the potential immediate lethal effect caused by trawling of heavy fishing gears. Although, the passage of the fishing gear re-suspends resting eggs making them more available for hatching, it may also damage the eggs and reduces their hatching success. Additionally, the hatching success of those eggs taken in the wake of the rubber discs was higher than those eggs taken in the wake of the door suggesting that the forces in the sediment associated with the heavier door damages the eggs more than those from the lighter discs. Consequently, when assessing the effect of trawling on copepod resting eggs, it is important to consider it at the level of the individual gear components that comes in contact with the seabed. It is also important to take into account the intensity of the fishing effort, as in certain areas where the effort is high, the seabed may be passed by a trawl many times a year [35] and the cumulative effect on the copepod eggs will need to be considered in recruitment perspectives.

\section{Conclusions}

This study has for the first time demonstrated that fishing with demersal otter trawls is both a source of mortality of the copepod eggs but also a source of re-suspension, which has the potential to increase recruitment to the water column. To fully assess the trade-off between mortality and recruitment on copepod ecology it is necessary to assess the extent to which these eggs would otherwise be disturbed, re-enter the water column and hatch. Therefore, it is also necessary to estimate the re-suspension due to bioturbation and storm events under different environmental conditions. We propose that more studies looking at the effect of trawling on the survival, re-suspension and overall recruitment from resting stages in marine sediments should be carried out.

\section{Acknowledgements}

The work was supported by the Eur-Ocean Network of Excellence PhD grant, the DHI-NTU Research Centre and Education Hub as well as the Danish Ministry for Independent Research Ung Elite Forsk grants 10-093759 and 10-094773 to GD, and The Danish National Science Research Council (grant no. 272-07-0485) awarded to BWH.

\section{References}

1. Camus T, Zeng C (2009) The effects of stocking density on egg production and hatching success, cannibalism rate, sex ratio and population growth of the tropical calanoid copepod Acartia sinjiensis. Aquaculture 287: 145-151.

2. Engel M,Hirche HJ (2004) Seasonal variability and inter-specific differences in hatching of calanoid copepod resting eggs from sediments of the German Bight (North Sea). J. Plankton Res 26: 1083-1093.

3. Marcus $\mathrm{NH}(1996)$ Ecological and evolutionary significance of resting eggs in marine copepods: past, present, and future studies. Hydrobiologia 320: 141-152.

4. Marcus NH, Boero F (1998) Minireview: The importance of benthicpelagic coupling and the forgotten role of life cycles in coastal aquatic systems. Limnol Oceanogr 43: 763-768.

5. Diekmann ABS, Clemmesen C, St. John MA, Paulsen M, Peck MA (2012) Environmental cues and constraints affecting the seasonality of dominant calanoid copepods in brackish, coastal waters: a case study of Acartia, Temora and Eurytemora species in the south-west Baltic. Mar Biol 159: 2399-2414.

6. Drillet G, Hansen BW, Kiørboe T(2011) Resting egg production induced by food limitation in the calanoid copepod Acartia tonsa. Limnol Oceanogr 56: 2064-2070.

7. Hairston NG, Van Brunt RA, Kearns CM(1995) Age and survivorship of diapausing eggs in a sediment egg bank. Ecology 76: 1706-1711.

8. Katajisto $\mathrm{T}(1996)$ Copepod eggs survive a decade in the sediments of the Baltic sea. Hydrobiologia 320: 153-159.

9. Marcus NH, Lutz R, Burnette W, Cable P (1994) Age, viability, and vertical distribution of zooplankton resting eggs from an anoxic basin. Evidence of an egg bank. Limnol Oceanogr 39: 154-158.

10. Sichlau MH, Hansen JLS, Anderson TJ, Hansen BW (2011) Distribution and mortality of diapause eggs from calanoid copepods in relation to sedimentation regimes. Mar Biol 158: 665-676.

11. Belmonte G, Puce M (1994) Morphological aspects of subitaneous and resting eggs from Acartia josephinae (calanoida). Hydrobiologia 292-293: 131-135.

12. Dharani G, Altaff K(2004) Ultra structure of subitaneous and diapausing eggs of planktonic copepod Sinodiaptomus (Rhinediaptomus) indicus. Curr Sci 87: 109-112. 
Citation: Drillet G, Hay S, Hansen BW and O'Neill FG (2014) Effects of Demersal Otter Trawls on the Re-suspension of Copepod Resting Eggs and its Potential Effects on Recruitment . J Fisheries Livest Prod 2: 1000114. doi:10.4172/2332-2608.1000114

Page 5 of 5

13. Hansen BW, Drillet G, Kristensen RM, Sorensen TF, Tottrup MT (2010) Production, hatching success and surface ornamentation of eggs of calanoid copepods during a winter at $57^{\circ}$ N. Mar Biol 157: 59-68.

14. De Stasio BT, Gilbert JJ, Alekseev VR (2007) Egg bank formation by aquatic invertebrates, in: Diapause in Aquatic invertebrates, Theory and human use. Monographiae Biologicae. Dordrecht, The Netherlands.

15. Marcus NH, Gengenbach JS (1986) Recruitment of individuals into the plankton: The importance of bioturbation. Limnol Oceanogr 31: 206-210.

16. Dolmer P, Kristensen T, Christiansen ML, Petersen MF, Kristensen S et al. (2001) Short-term impact of blue mussel dredging (Mytilus edulis L.) on a benthic community. Hydrobiologia 465: 115-127.

17. Ferré B, Guizien K, Madron DD, Palanques A, Guillen J, Gremare A (2005). Fine-grained sediment dynamics during a strong storm event in the inner-shelf of the Gulf of Lion (NW Mediterranean). Cont Shelf Res 25: 2410-2427.

18. O'Neill F, Simmons SM, Parsons DR, Best JL, Copland PJ et al. (2013 Monitoring the generation and evolution of the sediment plume behind towed fishing gears using a multibeam echosounder. ICES J Mar Sci 70: 892-903.

19. Ivanović A, Neilson RD, O'Neill FG (2011) Modelling the physical impact of trawl components on the seabed and comparison with sea trials. Ocean Engineering 38: 925-933.

20. O'Neill F, Summerbell K (2011) The mobilisation of sediment by demersal otter trawls. Mar Pollut Bull 62: 1088-1097.

21. O'Neill F (2013) The mobilisation of sediment and benthic infauna by scallop dredges. Mar Environ Res 90: 104-112.

22. Giannakourou A, Oriova TY, Assimakopoulou G, Pagou K (2005) Dinoflagellate cysts in recent marine sediments from Thermaikos Gulf, Greece: Effects of resuspension events on vertical cyst distribution. Cont Shelf Res 25: 2585-2596.

23. Siokou-Frangou I, Zervaoudaki S, Kambouroglou V, Belmonte G (2005) Distribution of mesozooplankton resting eggs in seabottom sediments of Thermaikos gulf (NW Aegean Sea, Greece) and possible effects of sediment resuspension. Cont Shelf Res 25: 2597-2608.

24. Brown L, Bresnan E, Summerbell K, O’Neill FG (2013) The influence of demersal trawl fishing gears on the resuspension of dinoflagellate cysts. Mar Pollut Bull 66: 17-24.
25. De Jonge V, Bouwman L (1977) A simple density separation technique for quantitative isolation of meiobenthos using the colloidal silica LudoxTM. Mar Biol 42: 143-148.

26. Folk RL (1954) The distinction between grain size and mineral composition in sedimentary-rock nomenclature. J Geol 62: 344-359.

27. Marcus NH (1991) Planktonic Copepods in a Sub-Tropical Estuary: Seasonal Patterns in the Abundance of Adults, Copepodites, Nauplii, and Eggs in the Sea Bed. Biol Bull 181: 269-274.

28. Marcus NH (1995) Seasonal study of planktonic copepods and their benthic resting eggs in northern California coastal waters. Mar Biol (Historical Archive) 123: 459-465.

29. Marcus N, Taulbee K (1992) Potential effects of a resuspension event on the vertical distribution of copepod eggs in the sea bed: a laboratory simulation. Mar Biol 114: 249-251.

30. Marcus NH (1984) Variation in the diapause response of Labidocera aestiva (Copepoda, Calanoida) from different latitudes and its importance in the evolutionary process. Biol Bull 166: 127-139.

31. Katajisto $T(2006)$ Benthic resting eggs in the life cycles of calanoid copepods in the northern Baltic Sea, in: Faculty of Biosciences. University of Helsinki: Helsinki.

32. Peck MA, Ewest B, Holste L, Kanstinger P, Martin M (2008) Impacts of light regime on egg harvests and 48-h egg hatching success of Acartia tonsa (Copepoda: Calanoida) within intensive culture. Aquaculture 275: 102-107.

33. Cook K, Bresnan E, Turrell E (2010) The influence of naturally occuring algal biotoxins on the biology of pelagic copepods: A review of the literature and data currently avalaible for scottish waters.

34. Mauchline J, Blaxter JHS, Douglas B, Tyler PA (1998) The biology of Calanoid copepods - Introduction. Advances in Marine Biology [33rd Ed]. Elsevier Academic Press. USA.

35. Rijnsdorp A, Buys AM, Storbeck F, Visser EG (1998) Micro-scale distribution of beam trawl effort in the southern North Sea between 1993 and 1996 in relation to the trawling frequency of the sea bed and the impact on benthic organisms. ICES J Mar Sci: Journal du Conseil 55: 403-419. 